\title{
CGMP-Dependent Protein Kinase 2
}

National Cancer Institute

\section{Source}

National Cancer Institute. cGMP-Dependent Protein Kinase 2. NCI Thesaurus. Code C34094.

cGMP-dependent protein kinase 2 (762 aa, $\sim 87 \mathrm{kDa}$ ) is encoded by the human PRKG2 gene. This protein is involved in cyclic GMP-dependent protein phosphorylation. 